\title{
International EIA Guidelines and the Nile Basin Countries EIA Experience
}

\author{
Rasha El Gohary, Associate Prof. \\ Central Laboratory for Environmental Quality Monitoring, \\ National Water Research Center, NWRC, Cairo, Egypt
}

doi: 10.19044/esj.2016.v12n17p482 URL:http://dx.doi.org/10.19044/esj.2016.v12n17p482

Abstract

The environmental impact assessment (EIA) was first required by the U.S. National Environmental Policy Act, which require environmental impact assessment of all major development projects to determine their potential for adverse effects on the environment. The environmental outlook for the Nile basin remains quite hazy. In the future there will be new environmental challenge stemming from population growth, increasing demands on agriculture, and climate change. This will put a huge burden on the environment. This research initiated to compare the international EIA guidelines in order to enhance the Nile Basin Countries experience to improve its practice in managing the environmental resources. This is due to the fact that Nile Basin Countries experiences face many challenges such as lack of capacity, data, proper guidelines, enforcement, and most importantly awareness of the environment protection sector or its effectiveness. Moreover; it requires reviewing and tools improvements to produce effective environmental management of development and engineering projects. Therefore, provision of detailed guidelines for EIA can help to improve the practice in the management of environmental resources. This paper reviews the EIA legislation in the Nile Basin Countries in comparison with international legislation and guidelines with emphasis on the EIA practice. The paper also intends to present selected international EIA guidelines in a comparative form and this is expected to raise awareness, professional experience of EIA issues, enhance EIA carrying capacity, and lead, ultimately, to improvements in available EIA legislations and guidelines and increase compatibility among them.

Keywords: EIA, EIA legislation, international EIA guidelines, Nile Basin Countries, Environmental Impact Management 


\section{INTRODUCTION:}

The Nile is the longest river in the world extending for $6695 \mathrm{~km}$. The Nile basin, 3 million km2, covers about $10 \%$ of the area of Africa, and 2.3\% of the world's land surface area. The Nile has 2 main sources: The Blue Nile; originating from Lake Tana, Ethiopia and the White Nile; originating from Lake Victoria, Uganda.

The Nile basin countries include: Burundi, Rwanda, Tanzania, Uganda, Kenya, Ethiopia, Democratic Republic of Congo, Eritrea, Sudan, Egypt (“Irrigation Potential”) Fig. (1). Over 200 million people live along more than $6700 \mathrm{~km}$ of river in 3,254,555 square kilometers.

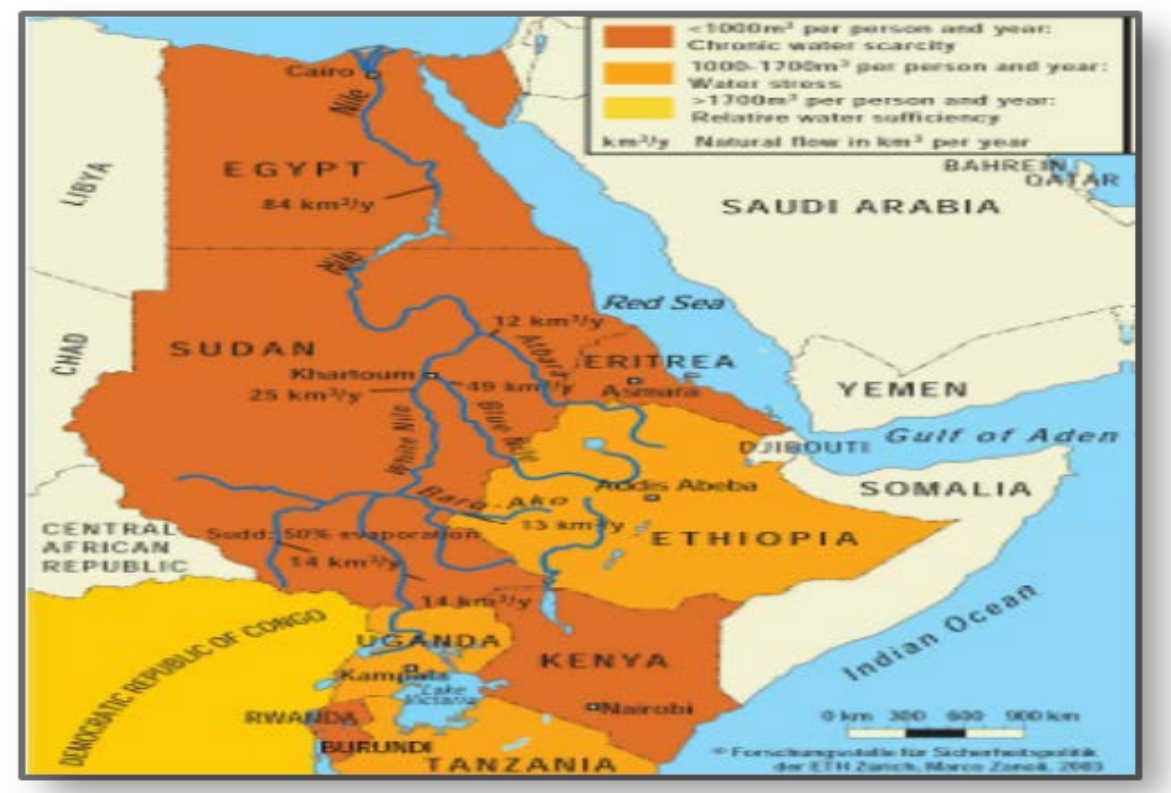

Fig.1 The Nile Basin ,(Mason 2005)

\subsection{Nile Basin Hydrology:}

The Blue Nile rises in the headwaters of Lake Tana, NW Ethiopia, a region of heavy summer rains, and is the source of floodwaters that reach Egypt in September; the Blue Nile contributes more than half of all Nile waters throughout the year. During flood time it also carries great quantities of silt from the highlands of Ethiopia; these now collect in Lake Nasser behind the Aswan High Dam, but for centuries they were left on the floodplain after the floods and helped replenish the fertility of Egypt's soils.

The White Nile (known in various sections as the Bahr-el-Abiad, Bahr-el-Jebel, Albert Nile, and Victoria Nile) rises in the headwaters of Lake Victoria in a region of heavy, year-round rainfall; unlike the Blue Nile, it has a constant flow, owing in part to its source area and in part to the regulating effects of its passage through lakes Victoria and Albert and the Sudd 
swamps. Other important tributaries of the Nile are the Atbara and Sobat rivers. The Gezira, or "island," formed between the Blue Nile and the White Nile as they come together at Khartoum is Sudan's principal agricultural area and the only large tract of land outside Egypt irrigated with Nile waters.

From Khartoum to the Egyptian border at Wadi Halfa (now submerged) and on to Aswan in Egypt, the Nile occupies a narrow entrenched valley with little floodplain for cultivation; in this stretch it is interrupted by six cataracts (rapids). From Aswan the river flows north 550 $\mathrm{mi}(885 \mathrm{~km})$ to Cairo, bordered by a floodplain that gradually widens to c.12 $\mathrm{mi}(20 \mathrm{~km})$; irrigated by the river, this intensively cultivated valley contrasts with the barren desert on either side. North of Cairo is the great Nile delta (c.100 mi/160 km long and up to $115 \mathrm{mi} / 185 \mathrm{~km}$ wide), which contains $60 \%$ of Egypt's cultivated land and extensive areas of swamps and shallow lakes. Two distributaries, the Dumyat (Damietta) on the east and the Rashid (Rosetta) on the west, each c.150 mi $(240 \mathrm{~km})$ long, carry the river's remaining water (after irrigation) to the Mediterranean Sea. Regular steamship service is maintained on the Nile between Alexandria (reached by canal) and Aswan; the Blue Nile is navigable (June through December) from Suki (above Sennar Dam) to Roseires Dam; the White Nile is navigable all year between Khartoum and Juba.

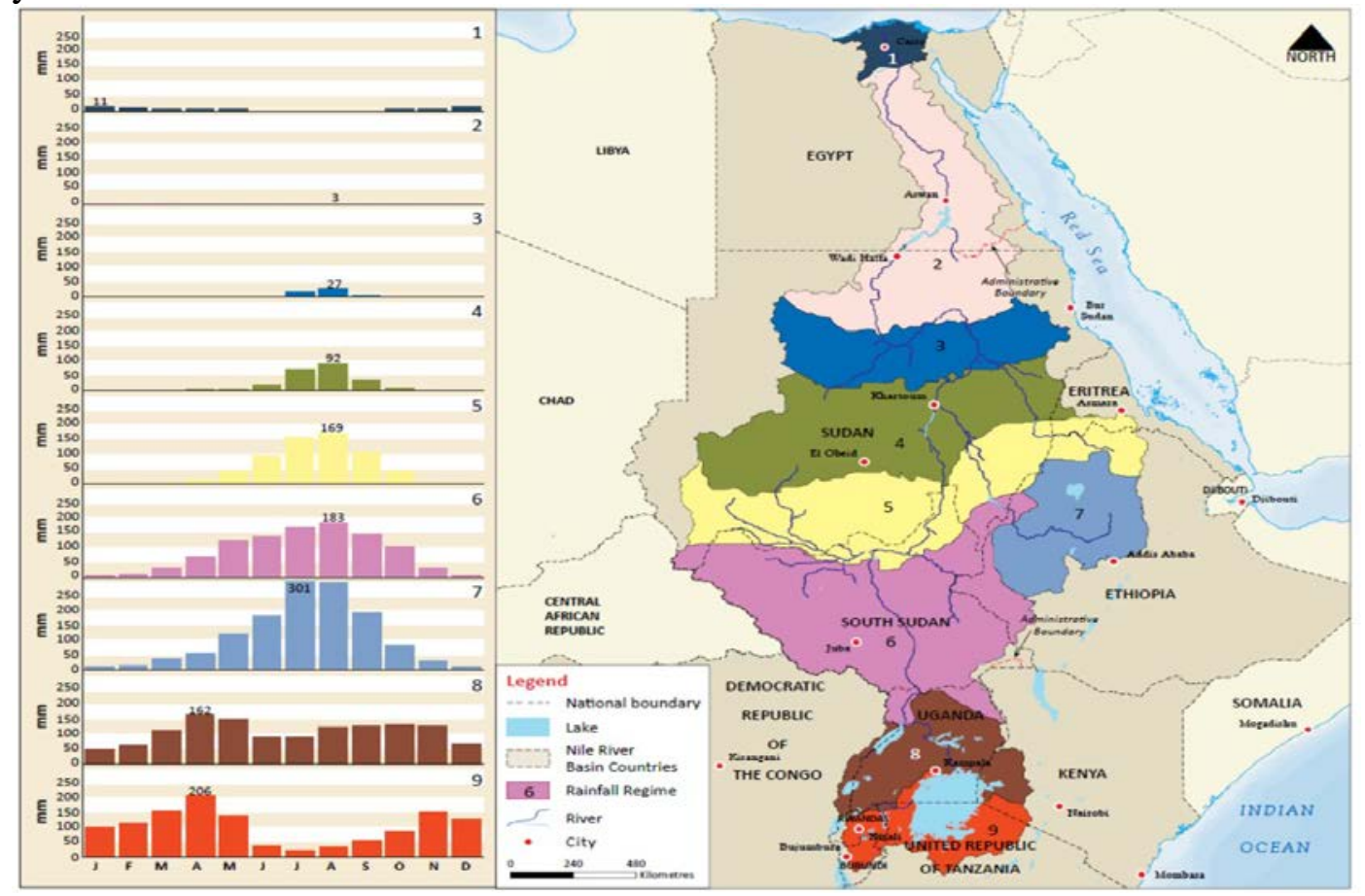

Fig. 2 Rainfall regimes over the Nile basin (base period is 1961 to 1990). 
It is evident from Table 1 that the Nile Basin countries depend on the Nile waters in varying degrees, depending on the availability of other water resources as rain and underground water. Egypt, Sudan and Eritrea are the most dependent countries on the Nile with a dependency ratio of 97, 77 and $56 \%$ respectively.

Table (1): Water resources in Nile Basin countries and their dependency on the Nile (FAO: Aquastat)

\begin{tabular}{|c|c|c|c|c|c|}
\hline \multirow[t]{2}{*}{ Country } & \multicolumn{5}{|c|}{ WATER RESOURCES } \\
\hline & $\begin{array}{c}\text { Average } \\
\text { precipitation } \\
1961-1990 \\
\text { IPCC } \\
\text { (mm/year) }\end{array}$ & $\begin{array}{l}\text { Average } \\
\text { precipitat } \\
\text { ion } 61-90 \\
\text { (km3/yea } \\
\text { r) IPCC }\end{array}$ & $\begin{array}{c}\text { Total renewable } \\
\text { water resources } \\
\text { (actual) } \\
\text { AQUASTAT } \\
\text { (cubic km/year) }\end{array}$ & $\begin{array}{c}\text { Total } \\
\text { renewable } \\
\text { water } \\
\text { resources } \\
\text { (actual) } \\
\text { AQUASTAT } \\
\text { (cubic } \\
\text { m/capita per } \\
\text { year) }\end{array}$ & $\begin{array}{c}\text { Dependency } \\
\text { ratio } \\
\text { AQUASTAT } \\
\text { (\%) }\end{array}$ \\
\hline Burundi & 1218 & 33.9 & 3.6 & 566 & 0 \\
\hline DRC & 1543 & 3618.1 & 1283.0 & 25183 & 30 \\
\hline Egypt & 51 & 51.4 & 58.3 & 859 & 97 \\
\hline Eritrea & 384 & 45.1 & 6.3 & 1722 & 56 \\
\hline Ethiopia & 848 & 936.0 & 110.0 & 1749 & 0 \\
\hline Kenya & 693 & 401.9 & 30.2 & 985 & 33 \\
\hline Rwanda & 1212 & 31.9 & 5.2 & 683 & 0 \\
\hline Sudan & 417 & 1043.7 & 64.5 & 2074 & 77 \\
\hline Tanzania & 1071 & 1012.2 & 91.0 & 2591 & 10 \\
\hline Uganda & 1180 & 284.5 & 66.0 & 2833 & 41 \\
\hline
\end{tabular}

\subsection{Nile Basin Socio-Economic Status:}

\subsubsection{Population:}

The population of the Nile Basin was 319.5 million in 2000 and 323 million in 2001. It is estimated that the current total population of the Nile Basin is about 350 million. It is expected to reach 548 million by the year 2030 (Fig 3).

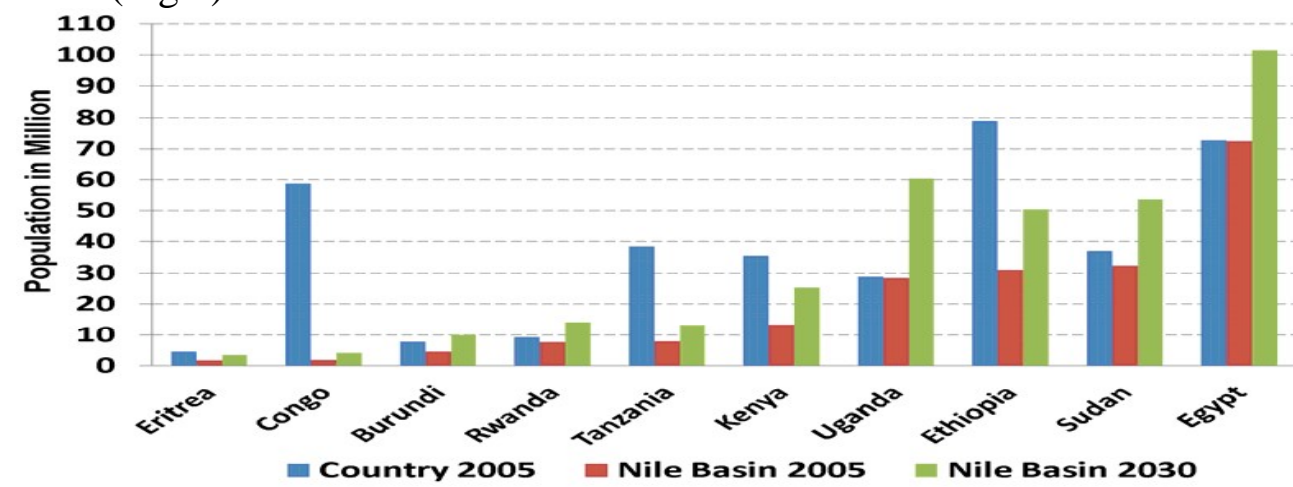

Fig. 3 The Population of the Nile Basin 2005/ 2030 
The environmental outlook for the Nile basin remains quite hazy. With the future will come new environmental challenge stemming from population growth, increasing demands on agriculture, and climate change. This will put a huge burden on the environment. Unchecked, pollution from industry and organic waste will rise exponentially in turn. This will certainly overwhelm the current infrastructure, which can't even handle the present levels of waste. It remains unclear whether the Nile can provide enough water to support adequate crops to feed such high population levels.

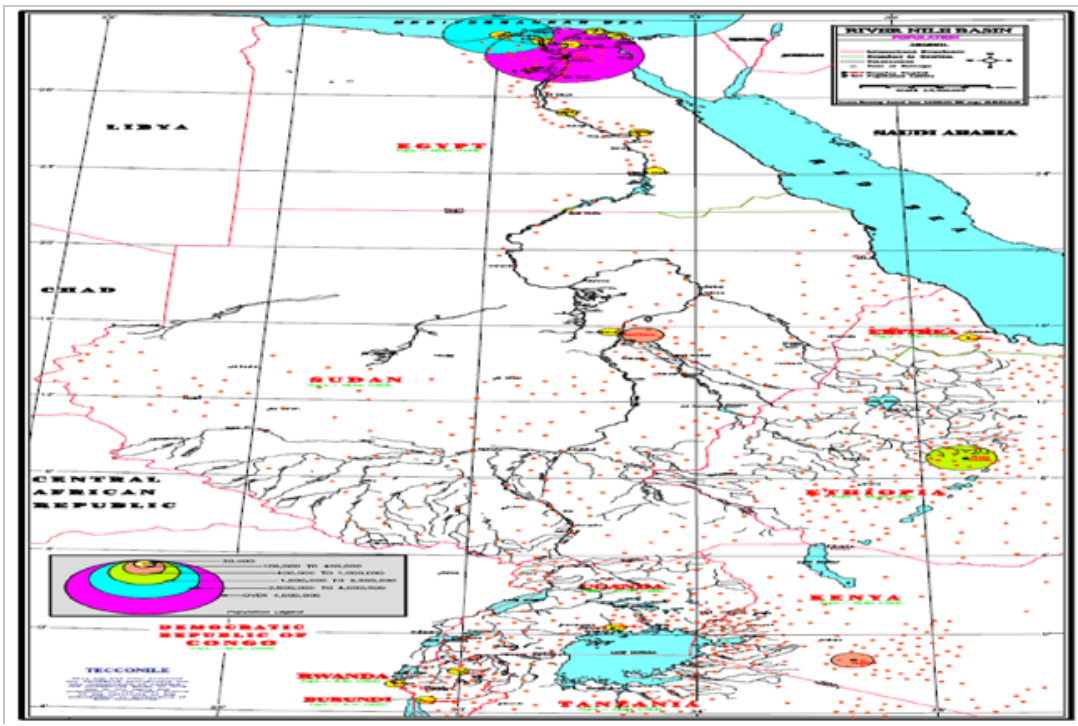

Fig. 4 Map Showing Population Distribution in the Nile Basin (Source: ITT Nile Group 2013

\subsubsection{Health}

Except for Burundi, Ethiopia and Sudan, where 40 per cent of children under the age of 5 years are underweight, the rest of the countries show the proportion of underweight children under the age of 5 years to be 20 per cent or less indicating overall low health per capita expenditure.

\subsubsection{Consumption}

With an annual change in the consumer price index of 424 per cent, it is difficult to meet basic consumption needs in the Democratic Republic of Congo as opposed to a change of less than 7 per cent in Egypt, Ethiopia and Kenya. However, part of this disparity in annual consumer price index change may be attributed to the effects of the ongoing conflict in the Congo.

\subsubsection{Investments}

Most basin countries have received low levels of direct foreign investments indicating that the economic environment is not conducive to greater trade, based on inflows of capital goods and services from foreign 
investments. However, this may now be changing with foreign commercial investors acquiring agricultural land in countries such as Ethiopia, Kenya, South Sudan, Sudan and Tanzania.

\subsubsection{Employment}

Apart from being the largest user of water, agriculture employs the largest proportion of available labor. It accounts for more than 80 per cent of employment in Ethiopia, Rwanda and Tanzania. Other potential employment sectors include industry and services which constitute 70 and 60 per cent of employment in Egypt and Kenya, respectively.

\subsubsection{Gender empowerment}

Taken as a measure of earned income (US\$ purchasing power parity equivalents, PPP), which explains how income would be distributed among gender groups, it is lowest in Egypt (0.26) and highest in Uganda (0.6), indicating that there are significant differences in earned incomes between the genders. For this measure, Ethiopia represents an equal measure in earned income (0.48), suggesting that earned income is nearly equally distributed between the genders.

\subsubsection{Poverty mapping}

The type of poverty expressed is income poverty. It is related to the ability of people to meet their income needs. This form of poverty is widespread, since many of the Nile countries have agricultural economies with rural agrarian populations. The poverty map as shown in Fig.5 highlights variation aggregated by national-level indicators which often hide important differences among different regions and countries in the Nile Basin. In almost all countries, these differences exist and can often be substantial. For the countries presented in Fig. 5, recent welfare and economic well-being surveys commissioned by the World Bank reveal that poverty levels are related to rural and urban inequalities and access to services (World Bank, 2002, 2003, 2005, 2006, 2007). In Ethiopia, unique geographical disparities occur, but on average, households are $10 \mathrm{~km}$ away from a dry weather road and $18 \mathrm{~km}$ from public transport services. Therefore, it takes significantly longer to reach markets in rural Ethiopia than elsewhere. Another poverty attribute is land degradation whereby soil nutrient depletion continues at a faster rate than replenishment from mineral fertilizers. Due to population pressure, it is found that one in five rural Ethiopian households lives on less than 0.08 ha person' which yields, on average, only slightly more than half the daily cereal caloric needs per person, given current cereal production technologies. Gender inequalities are widespread; for example, girls are 12 per cent less likely than boys to be 
enrolled in school. In Uganda, it is found that most of the poor live in rural areas. They were characterized as subsistence farmers with limited access to infrastructure. The poor were 97 per cent rural, while the rich were classified as being more than 40 per cent urban. Inequality in Uganda continues to rise as the gap in mean income in rural and urban areas has widened, and inequality within both urban and rural areas has increased.

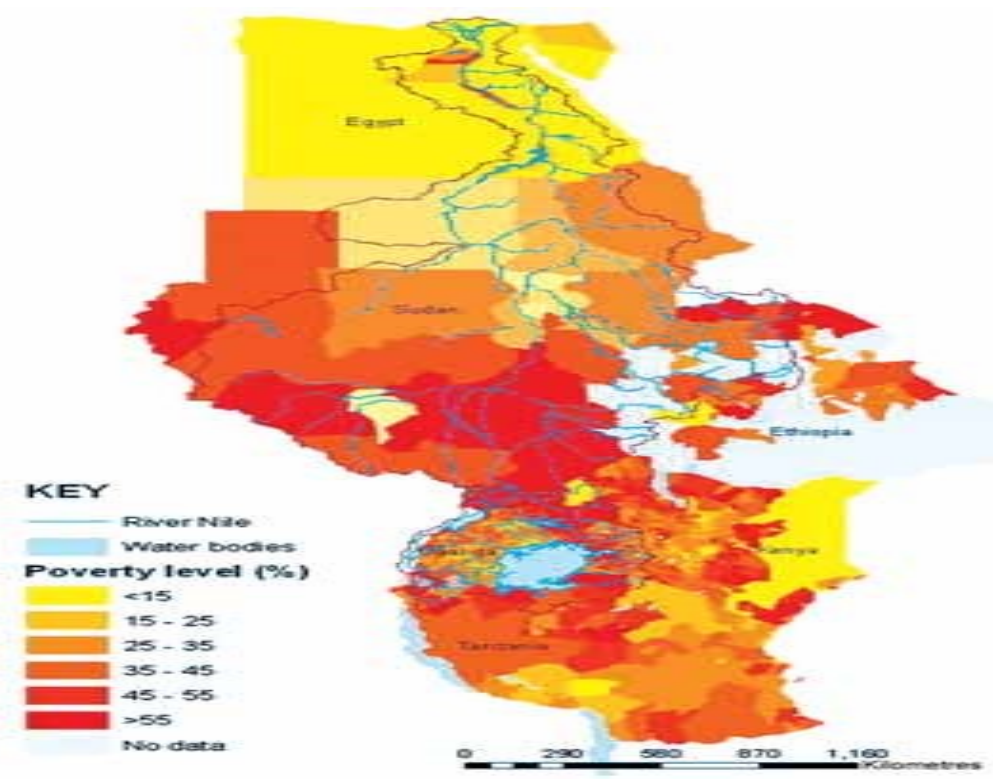

Fig. 5 Poverty levels in the Nile Basin (\%)

(Source: Kinyangi et al., 2009)

\subsection{Common Causes of Environmental Threats for Basin Countries}

To summarize the environmental threats as shown in Table 2, although these are not the only environmental concerns in each country, they represent the most urgent threats. Several common themes can be seen deforestation in seven countries and soil erosion in every country. Uganda and Egypt stand out with respect to draining and filling of wetlands and attendant loss of habitat and potential adverse impacts on water quality. Only Egypt is experiencing a threat to soil productivity from increasing groundwater tables and rising soil salinity.

Table 2. Summary of Basin-wide Common Causes and Priority Environmental

Threats Reported for Basin Countries

Common Causes for Environmental Threats

\begin{tabular}{|c|c|}
\hline $\begin{array}{l}\text { Basin-wide } \\
\text { causes }\end{array}$ & $\begin{array}{l}\text { Policy, governance, institutional and capacity constraints, insufficient environmental education } \\
\text { and awareness, limited access to environmental knowledge and information (including relevant } \\
\text { scientific data), unclear tenure and inadequate access to resources for local stakeholders, } \\
\text { inadequate management of protected areas and other environmental hot spots }\end{array}$ \\
\hline \multicolumn{2}{|r|}{ Priority Environmental Threats by Country } \\
\hline & l erosion, degradation of river banks and lakeshores, mini \\
\hline
\end{tabular}




\begin{tabular}{|c|c|}
\hline DR Congo & River and lake pollution, deforestation, soil erosion, wildlife hunting \\
\hline Egypt & $\begin{array}{l}\text { Water and air pollution, filling of wetlands, desertification, waterlogging and soil salinity, } \\
\text { sanitation, river bank degradation }\end{array}$ \\
\hline Ethiopia & $\begin{array}{l}\text { Deforestation, overgrazing, soil erosion, desertification, sanitation, loss of biodiversity } \\
\text { (including agrobiodiversity), floods, droughts }\end{array}$ \\
\hline Kenya & $\begin{array}{l}\text { River and lake pollution (point and non-point source), deforestation, desertification, soil erosion, } \\
\text { sedimentation, loss of wetlands, eutrophication and water weeds }\end{array}$ \\
\hline Rwanda & $\begin{array}{l}\text { Deforestation, soil erosion, degradation of river banks and lake shores, desertification, wildlife } \\
\text { hunting, overgrazing }\end{array}$ \\
\hline Sudan & $\begin{array}{l}\text { Soil erosion, desertification, pollution of water supplies, wildlife hunting, floods, droughts, } \\
\text { sanitation, deforestation, }\end{array}$ \\
\hline Tanzania & $\begin{array}{l}\text { Deforestation, soil degradation, desertification, river and lake pollution, poaching and shortage } \\
\text { of potable water }\end{array}$ \\
\hline Uganda & $\begin{array}{l}\text { Draining of wetlands, deforestation, soil erosion, encroachment into marginal lakeshore and } \\
\text { riverine ecosystems, point- and non-point source pollution }\end{array}$ \\
\hline
\end{tabular}

\section{NILE BASIN ENVIRONMENTAL IMPACT ASSESSMENT}

The environmental impact assessment (EIA) was first required by the U.S. National Environmental Policy Act, which required environmental impact assessment of all major development projects to determine their potential for adverse effects on the environment. The EIA took a pro-active, preventive approach to environmental management, rather than relying solely on environmental remediation and mitigation. The concept later found its way into international conventions and has garnered broad acceptance as an effective means to prevent environmental degradation as a result of development projects. Although EIA provisions have not typically been applied to agricultural development projects, expansion of the application of EIA has been recommended as one way to reduce adverse impacts of irrigation expansion, including degradation of river basins Postel, (1996).

The first three stages of the impact assessment process-screening, preliminary assessment, and scoping-are extremely important in determining the extent and focus of the impact assessment required. The purpose of screening is to decide whether or not a project requires assessment and, if so, the level of assessment necessary. Past experience shows that certain types of projects are unlikely to have serious adverse environmental impacts. Other types have the potential to cause significant impacts and routinely require a comprehensive EIA. The extent of EIA required depends on the scale and complexity of the project and the nature of the local environment. Within each riparian country, guidance to assist with the screening process may take several forms: screening criteria such as size, cost, or location of the project; lists of projects that do or do not usually require an EIA; and checklists of project and sensitive environmental conditions that require further investigation. The types of projects that generally require an EIA include those that involve:

- Significant change in renewable resources use 
- Substantial change in farming or fisheries practice

These account for transboundary impacts, but obviously screening criteria also need to include potential for air, water, and solid and hazardous waste discharges as well.

Strategic environmental assessment: A Strategic environmental assessment (SEA) is a pro-active tool for planning, policymaking, and environmental management. It is employed at a higher level and at an earlier stage of management than traditional EIAs. An SEA creates a framework in which to focus environmental impact assessment, environmental management, and environmental monitoring. At present SEA is a generic term not yet linked to a clearly established methodology.

While a few countries have attempted to codify SEA techniques, the limited practical experience available illustrates a range of goals, tools, techniques, and SEA processes. This process has recently evolved in response to the shortcomings of project-specific EIAs Mason, S.A., (2003).

In the Nile Basin countries, EIA process has been carried since mideighties, on mainly large projects funded by Foreign Funding agencies like; World Bank, European Union, USAID etc. Nevertheless, various countries formulated environmental policies and enacted environmental laws with the assistance from the funding agencies. The acts promulgated in various Nile Basin countries are;

- Egypt: Environment Protection, Law No.4, of 1994,

- Uganda: Environmental Management Act in 1995,

- Sudan: Environmental Management Act in 1998,

- Rwanda: Environmental Management Act in 2004,

- Kenya: Environmental Management and Coordination Act in 1999.

These laws are implemented through the Environment Regulations and procedures established in each country. Compliance to the procedures varies from country to country depending on the attitude, legal and institutional frameworks, political will and competence of the private sector (mainly the Consultants/Environmental assessors).

\section{THE EIA PROCESS INTERNATIONAL ORGANIZATIONS}

The EIA guidelines of the US, WB, FAO, and EU are briefly described here and following is a comparison table to highlight major issues in each of them. It is very important to note that the FAO guidelines are for irrigation and drainage projects (sectoral guidelines) while the rest are not general guidelines.

\subsection{The US-CEQ EIA Guidelines}

The US EIA guidelines (Corbit, 1990 and Canter, 1996), were produced initially by the Council on Environmental Quality (CEQ) in 1971 
and were amended in 1973. General comments include in the CEQ regulations regarding the preparation of EISs can be summarized as follows:

- EISs should be analytic rather than encyclopedic.

- Impacts should be discussed in proportion to their significance.

- $\quad$ EISs should be concise.

- EISs should state how alternatives considered and decisions made, based on the EIS, will or will not achieve the requirements of environmental laws and policies.

- Alternatives discussed should be limited to those which are expected to be considered by the agency decision-maker.

- The agency should not commit resources prejudicing selection of alternatives before making a final decision.

- EISs should be a mean of assessing the environmental impact of the proposed action, rather than a mean of justifying the decisions already made.

- A systematic and interdisciplinary approach should be used to prepare EISs.

- $\quad$ EISs should be written in plain language and appropriate graphics may be used so that decision makers and the public can readily understand the documents.

- Public participation should be actively sought during the scoping process and in the early planning stages of the project to identify significant issues.

In the US the EIA is guided through stages described as follows: Screening, Scoping, EI Study and EIS Review. SEA is provided by carrying out EIA on policies, strategies and legislation. In the screening stage the documents provide a list of projects with categorical exclusion and a brief description of the content of an EA.

In determining the scope of environmental impacts, CEQ requires that agencies consider three types of actions, three types of alternatives, and three types of impacts. These include:

A. Actions (other than unconnected single actions) which may be; connected, cumulative, or similar actions.

B. Alternatives, which include; No action alternative, other reasonable courses of action, and mitigation measures (not in the proposed action).

C. Impacts, which may be direct, indirect, or cumulative.

For the EI study stage, the CEQ guidelines give a detailed document on the methods and tools of assessment of Environment Impacts. It usually starts with a description of the proposed action. Following the project description, a baseline Study is required. To establish the baseline requires a study of the environmental setting or location and conditions under which the proposed action is to take place. A detailed description on how to 
identify different types of impacts and affected environments in addition to impact evaluation methods is given for all types of project alternatives including the mitigation measures. In the EIS Review Stage, the Guideline provides guidance on timing issues, reporting, public participation methods, and the steps of review and decision making including monitoring as appropriate.

\section{Summary of World Bank Environmental Assessment Procedure WB, (1999)}

In the WB the EIA is guided through stages described as follows Mason, S.A., (2005):

I. Screening: All proposals submitted to the World Bank must undergo environmental screening. Environmental screening results in a project being classified into one of three EIA categories:

- Category-A proposals require full EA;

- Category-B proposals require partial EA; and

- Category-C proposals do not require EA.

II. Scoping: Once a project is categorized, a scoping process is undertaken to identify the key issues and develop the Terms of Reference (TOR) for the EA.

III. Public Consultation: Consultation with affected communities is recognized as the key towards identifying the environmental impacts and designing their mitigation measures. The consultation with affected groups and local NGOs, during at least two stages of the EA process, is almost compulsory:

- At the scoping stage, shortly after the EA category has been assigned,

- After a draft EA report has been prepared

IV. Preparation of EA Report: The EA report shall include Executive Summary, Policy, Legal and Administrative Framework, Project Description, and Baseline Data.

V. Appraisal Process: Includes Impact Assessment, Analysis of Alternatives, and Public Consultations.

VI. Implementation Plan: Shall include Mitigation or Management Plan, Environmental Monitoring Plan, and Project Implementation.

VII. Environmental Impact Evaluation: EIA Review and Project Appraisal (Evaluation of EIS): Once the draft of EIA report is finalized, the borrower submits it to the Bank for review by the environmental specialists. If it was found to be satisfactory, then the Bank project team is authorized to proceed with the next step of the appraisal of the project.

\subsection{The FAO EIA Guidelines (for Irrigation and Drainage Projects)}


FAO (Daugherty and Hall, 1995) describes and recommends an EIA process that should be used and applied in its projects.

The main steps of the EIA process include Dougherty C., and Hall A. W (1995),: Screening, Scoping, Prediction and Mitigation, Management and Monitoring, Audit.

In the screening stage, the project is supposed to be categorized, and this results in a decision on whether the project requires a full EIA or not to be carried out. This decision may be made by size (of land, flow of water to be diverted or capital expenditure) or site specific information. However, it stipulates that the screening process is country specific depending on the laws and norms of the country.

In the scoping stage, the most critical environmental issues to study are determined. This is taken to be the most important stage of the entire EIA process. The main output of the scoping study will be the TOR's of the EI study. The main techniques for scoping assessments include; baseline studies, Checklists, Matrices, and Network Diagrams.

During the Detailed Prediction and Mitigation studies stage, quantifying the environmental impacts and proposing mitigation measures is done. All the impacts should be compared to the "without project" scenario. The major techniques applied include mathematical modeling, Expert Advice (especially with experts familiar with the locality), Checklists, Matrices, Network Diagrams, Graphical representations and overlays. After the impacts have been quantified, they can be compared by applying weightings to them or using economic cost-benefit analysis or a combination of the two.

The EI Statement from step above also provides a detailed plan for managing and monitoring of the environmental impacts both during and after implementation, this is known as the Environmental Action Plan or Environmental Management Plan. A clear definition should be made to which agencies are responsible for data collection, collation, interpretation and implementation of management measures. The guidelines go ahead to give the weak areas of concern for monitoring, and emphasizes the use of satellite imagery as a technique for monitoring FAO, (1995).

The Audit stage is carried out sometime after implementation of the project, it is provided to serve as a feedback and learning function for the EIA process. It is to be done by a separate team of specialists. It should include an analysis of the technical, procedural and decision-making aspects of the EIA. It includes an analysis of the Baseline studies, accuracy of predictions, and the suitability of mitigation measures. Also the procedural aspects of the EIA process should be included, that is, the efficiency of the procedure, the fairness of the public involvement measures and degree of coordination of roles and responsibilities. Plus, decision making aspects like 
utility of the process for decision making and implications of the development.

\subsection{The European Union EIA Guidelines}

These guidelines came about after an EU Directive of 1997, and are written to be practiced in the whole EU region. The EU published four detailed and concise documents entailing the current required EIA practice in June 2001 EU, (1999). Each of these documents describes a specific stage in the EIA process. The EIA process is in four stages: Screening, Scoping, EI Study and EIS Review.

The screening stage is there to determine whether a project requires EIA or not. This document provides a step by step practical guidance on how to undertake screening. In addition to that, the document goes ahead to describe the screening tools to be used perform an EIA screening test on a project.

In the scoping stage, the content and extent of matters to be included in the environmental information are covered. The document provides guidance on scoping procedures and methods. In addition to that the document describes the kind of information and outputs to be looked out for from the project during the scoping stage.

For the EI study stage, the EU guidelines give a detailed document on the methods and tools of assessment of Environment Impacts. The guidelines give the pros and cons of every method, and under what circumstances the method or tool can be applied. In addition, the guidelines give what kind of information each kind of method can provide and concludes by giving a general approach to a Study.

In the EIS Review Stage, the Guidelines provides guidance on how to establish whether the EI Statement submitted is adequate for the decision on development or not. It provides practical guidance on how the review should be carried out. It provides a checklist to be used as a tool for guiding on the adequacy of the EI Statement.

\subsection{Comparison of International EIA Guidelines}

A brief description of selected international EIA guidelines was provided and a brief comparison is given in Table 3. There are many areas where the older guidelines are more detailed than recent ones such as the US and WB as compared to the EU guidelines. However, the US guidelines provide timing issues more detailed than the WB and on the other hand the WB provide more detailed consideration of trans-boundary issues than the US. 
Table 3 Comparison between US, WB and EU EIA guidelines

\begin{tabular}{|c|c|c|c|c|}
\hline No. & Issue & US & WB & $\mathbf{E U}$ \\
\hline 1 & EIA time frames & $\begin{array}{l}\text { Time limits are defined between } \\
\text { various stages of EIA process }\end{array}$ & Exist but not very clear & Not defined \\
\hline 2 & EIA screening & $\begin{array}{l}\text { Clear on exempted projects but not } \\
\text { well explained for other projects }\end{array}$ & $\begin{array}{l}\text { Detailed screening lists } \\
\text { available }\end{array}$ & $\begin{array}{l}\text { step by step practical } \\
\text { guidance on how to } \\
\text { undertake screening }\end{array}$ \\
\hline 3 & EIA scoping & $\begin{array}{l}\text { Very well described with methods } \\
\text { clearly explained }\end{array}$ & Detailed & $\begin{array}{l}\text { Detailed Issues to be covered by EIAs are } \\
\text { explicitly specified }\end{array}$ \\
\hline 4 & $\begin{array}{l}\text { Public } \\
\text { participation }\end{array}$ & Methods, time, and forms specified & $\begin{array}{l}\text { For all category A and B } \\
\text { projects the borrower } \\
\text { consults project-affected } \\
\text { groups and local NGOs. }\end{array}$ & $\begin{array}{l}\text { Public access to EIA } \\
\text { report, and opportunity to comment (Article 6). }\end{array}$ \\
\hline 5 & EIA Report & Contents detailed & Contents detailed & Contents detailed \\
\hline 6 & Quality review & Required and explained & Required and explained & required \\
\hline 7 & $\begin{array}{l}\text { Environmental } \\
\text { baseline studies }\end{array}$ & $\begin{array}{l}\text { Requirements } \\
\text { listed }\end{array}$ & $\begin{array}{l}\text { What should be reported is } \\
\text { listed }\end{array}$ & $\begin{array}{l}\text { Coverage of a range of issues (health, social, } \\
\text { economic, cultural( required }\end{array}$ \\
\hline 8 & $\begin{array}{l}\text { Assessment of } \\
\text { alternatives }\end{array}$ & $\begin{array}{l}\text { Alternatives are listed including the } \\
\text { 'no action alternative }\end{array}$ & $\begin{array}{l}\text { Investment alternatives are } \\
\text { required }\end{array}$ & $\begin{array}{l}\text { Alternatives for project } \\
\text { site and scenario and the } \\
\text { "do-nothing" alternative } \\
\text { required; }\end{array}$ \\
\hline 9 & $\begin{array}{l}\text { Mitigation } \\
\text { measures and } \\
\text { impact } \\
\text { management }\end{array}$ & $\begin{array}{l}\text { Included in the } \\
\text { alternatives } \\
\text { evaluation }\end{array}$ & $\begin{array}{l}\text { Description of mitigation } \\
\text { measures requirements are } \\
\text { given }\end{array}$ & $\begin{array}{l}\text { measures to avoid, eliminate or compensate } \\
\text { possible impacts required }\end{array}$ \\
\hline 10 & EIA reporting & Explained and timeframe set & Not specified & $\begin{array}{l}\text { Precise requirements for } \\
\text { EIA report contents and } \\
\text { the reporting procedure }\end{array}$ \\
\hline 11 & Decision making & Well explained & Briefly described & Not defined (by each member state) \\
\hline
\end{tabular}




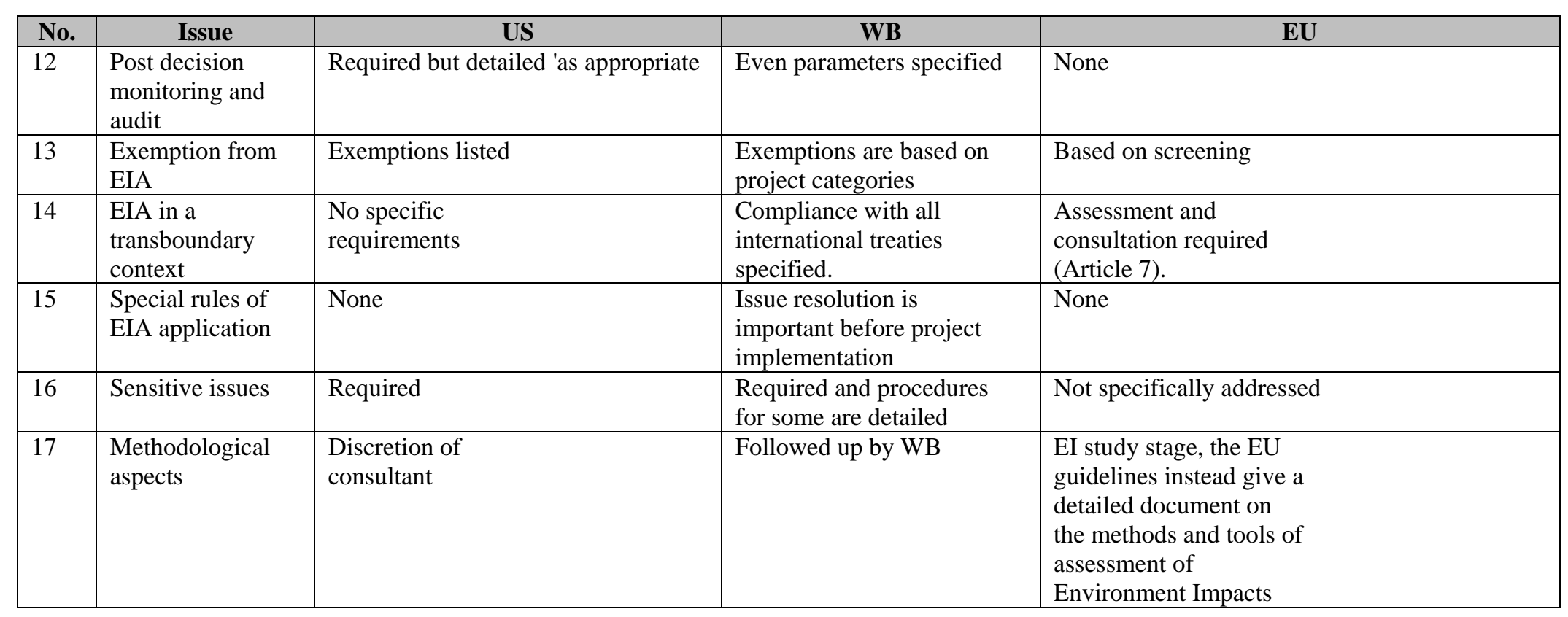




\section{NILE BASIN COUNTRIES EIA EXPERIENCES}

\subsection{Egypt EIA Experience}

In Egypt Environmental Affairs are managed by the Egyptian Environmental Affairs Agency (EEAA). It has the responsibility of supervising the EIA process in Egypt. The report from Egypt did not contain the EIA guidelines. Though from the report provided, it was able to see that the two major stages: Screening and then the EI Study. In the screening stage, the project is examined to find where under which category of projects it lies. Projects in Egypt are grouped into; White list projects (projects with minor environmental impacts), Grey list (projects which may result in substantial environmental impacts), and Black List (projects for which a complete EIA must be carried out due to the magnitude and nature of their potential impacts).

For Grey list projects, EEAA may require a "scoped EIA" whose scope is specified by EEAA on the basis of information presented by the developer. For the Black list of projects, the guidelines are subdivided depending on the nature of the project, that is, A (guidance for Grey List projects), $\mathrm{B}$ (guidance for wastewater treatment works), $\mathrm{C}$ (guidelines for ports and Harbors), D(guidelines for industrial zones), D(guidelines for Tourist Activities).

It entailed some modifications to the division between the three categories A, B, and C, varying in the severity of possible environmental impacts, as well as the expansion of the lists of facilities in each category to include additional ones, with the purpose of minimizing errors in categorization. In this respect, and in line with the development of sectoral guidelines, the development of sector-specific EIA forms has taken place. In 2000/2001, specific B category forms were developed for the petroleum and tourism sectors. Table 4 represent the Evolution of EIA's Reviewed by EEAA.

Table 4. Temporal Evolution of EIA's Reviewed by EEAA.

\begin{tabular}{ccc}
\hline Year & Number of EIA's Reaching EEAA & Number of CAA's \\
\hline 1994 & 7 & 3 \\
1995 & 26 & 4 \\
1996 & 41 & 10 \\
1997 & 87 & 13 \\
1998 & 276 & 25 \\
1999 & 11056 & 46 \\
2000 & 10315 & 52 \\
\hline
\end{tabular}

\subsection{Sudan EIA Experience}

In Sudan, the legislation pertaining to environmental management is found in the Environment Policy Act of 2001 which, under section 9, stipulates that EIA be undertaken where the quality of the environment is to 
be adversely affected upon implementation of major development projects. The authority responsible for environment management is the Higher Council for Environment and Natural Resources (HCENR).

The general process for conducting EIA is presented in Fig6. It is composed of the preparation of an EIA by the project developer or proponent' environmental consultant and its submission it to the HCENR for evaluation. Upon final acceptance of the EIA the project proponent is given a permission to implement the project.

These EIAs, although done in accordance with prevailing legislation and guidelines, reveal the serious shortcomings in conducting the assessments for the projects such as the absence of major steps in conducting EIA, Cost-Benefit Analysis, or post project follow up. These lapses can be accounted for in upgrading policies, legislation and guidelines of the Sudan.

Most of the Sudanese practices failed in some major areas in EIA such as: alternative analysis: were not considered in most cases, timing delay: most of the studies started after the implementation of the project therefore the EIA never integrated with the planning stage of the project and that always introduce many financial and technical problems in the long term of EIA and project integration, poor public participations and bad interaction with the decision making process, limited tools applied which in most cases were insufficient for specific projects, EMP in most cases was not complete and not considering the cost-benefit analysis, responsibilities or monitoring schedule. Poor governmental reviewing decreased the monitoring process and sustainability of the EIA mitigations. Advantageously, the EIA practices are becoming more popular in Sudanese development planning and there are lots of arguments about enhancing the legislation and regulations Ahmed, M. I., and Abdella, L. D (2006). .

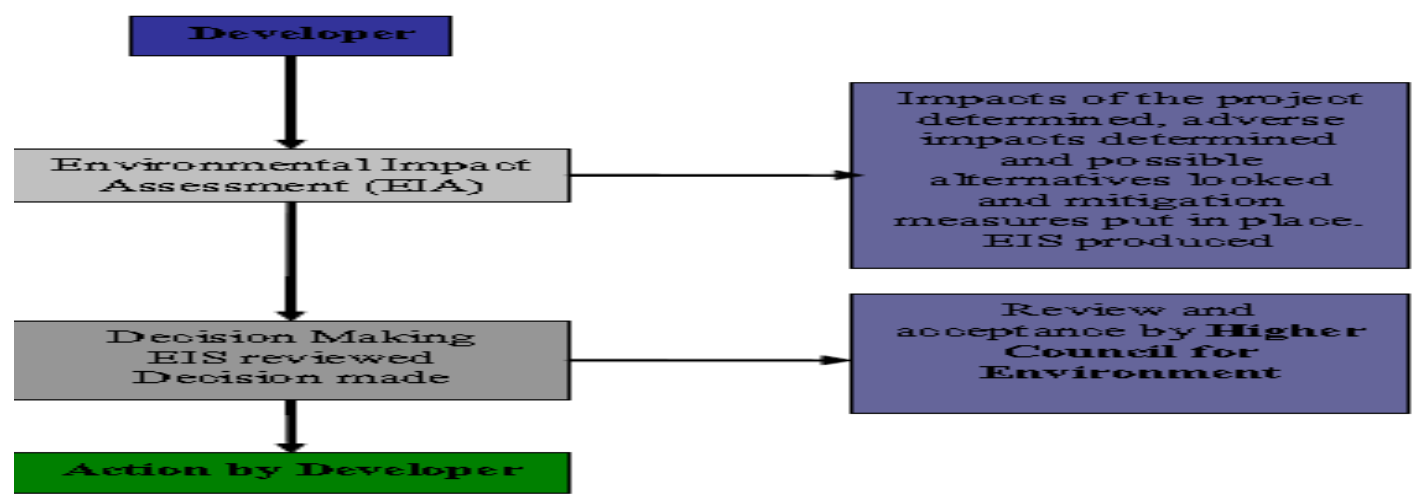

Fig. 6 EIA process in the Sudan

\subsection{Burundi EIA Experience}

The Ministry of Water, Environment, Land Management and Urban Planning was reorganized by Decree No. 100/108 of November 22, 2005. 
This Ministry was known as MINATET (Ministère de l'Aménagement du Territoire, de l'Environnement et du Tourisme) at its inception in 2005, changed to MINEATP (Ministère de l'Environnement, de l'Aménagement du Territoire et des Travaux Publiques) in 2007, and since 2009, has been known as MEEATU. Although this Ministry has changed its name several times because of some departments moving or being added, its basic responsibilities have remained the same. It is empowered for everything that concerns the development and implementation of national policy in the field of water, environment, land management, and the urban sector.

It has the following objectives: promoting a coordinated management of the environment; sound management of land, water, forests, and air; preservation of ecological balance; and conservation of biodiversity.

\section{The Environment Act, 2000}

Since June 30, 2000, the Republic of Burundi had made an Act 1/010 known as the environment Act paving a way to elaborating Environment Assessment. The guidelines on how to carry out the Environment Assessment are outlined in chapter 3 under clauses 21 and 24.

The clause 21 authorizes one to introduce the tender application for the environment assessment, while clause 22 presents the authority through which the application should be submitted to the Environment Administration. The clause 23 highlights the steps of methodology to be followed. At the end, the clause 24 informs that a decree should be made to show the list of different categories of operating activities or documents needed in the procedural study of environment impact assessment.

However, the clause 34 stresses that the activities of construction or public infrastructure such as roads, dams, dykes, bridges or airports should be sent for checking that the procedure of environment study has been followed. Besides, all plans dealing with rural or urban landscaping, especially the distribution of land for the purpose of industrial development, need a well-developed layout to be submitted for procedural checkups.

As regards the work relating to the supply of water intended for consumption, clause 40 of the Code of the environment said: "the work of the removal of water intended for human consumption are subject of a declaration of public interest of the part of the Minister of public health and the Minister responsible for the environment, acting by joint order". For the purposes of preserving the quality those waters, the Above statement establishes around the sources, sinks, points of the distribution or any other structure intended to supply drinking water, the protection boundaries established in accordance with the law on the hydraulic public property in its title VII, chapter II related to the protection boundaries of drinking water. 
The clause 45 constitutes a provision of protection of water against pollution. Specifically, it prohibits spills, flows, discharges, deposits direct or indirect of any kind, and more generally all activities or facts likely to cause or increase the pollution of surface or underground water of whatever the origin.

Finally, the clause 52 of the same code stipulates that the works, engineering activities and landscaping, capable of altering the balances hydraulic water systems, the flows of water or the configuration of the banks of the rivers or lakes, to harm the preservation of aquatic species are subject to the procedure for the impact study and cannot be achieved only after the favorable opinion of the Minister of the environment.

As regards the forests, the clause 69 of the code of the environment recognizes this as a property of common interest. Thus, they must be protected and exploited by taking into account their impact on the Burundian environment. The clause 70 stipulates: "that they are public or private, forests must be protected against any form of degradation or destruction resulting in particular from abusive bush clearing abusive, pollution, bush burning or fire, agricultural overexploitation or livestock overgrazing, diseases or the inappropriate introduction of species".

\subsection{Ethiopia EIA Experience}

The most important step in setting up the legal framework for the environment in Ethiopia has been the establishment of the Environmental Protection Authority (EPA) by proclamation No. 9/1995. According to this proclamation the Environmental Protection Authority (EPA) has amongst its 'powers and duties [8]:

- To prepare environmental protection policy and laws; and, upon approval, follow up their implementation.

- To prepare directives and systems necessary for evaluating the impact of social and economic development projects on the environment; follow up and supervise their implementation.

The Federal Government of Ethiopia is in the process of passing number of proclamations that are aimed at providing the legislative instruments for the implementation of the national environmental policy objectives and strategies. The following environmental protection proclamations were enacted by the council of Representative of FDRE.

\section{Environmental Impact Assessment (Proclamation No. 299/2002)}

This Proclamation (No 299/2002) aims primarily at making the EIA mandatory for categories of projects specified under a directive issued by the EPA. The law specifies the projects and activities that will require an environmental impact assessment (EIA). 
The proponent of the project must prepare the EIA following the format specified in the legislation. The EPA will then review the EIA and either approve the project (with or without conditions) or reject it. Under this legislation, the EPA has to prepare procedures, regulations, environmental guidelines and standards for the EIA.

Environmental guidelines are among the tools for facilitating the consideration of environmental issues and principles of sustainable development and their inclusion in development proposals. The Proclamation requires, among other things:

- Specified categories of projects to be subjected to an EIA and receive an authorization from the EPA or the relevant regional environmental agency prior to commencing implementation of the project.

- Licensing agencies to ensure that the requisite authorization has been duly received prior to issuing an investment permit, a trade or operating license or a work permit to a business organization.

Procedures that need to be followed in the process of conducting an environmental impact assessment are described in the Proclamation. Thus, a project developer is expected to act as follows:

- Undertake a timely environmental impact assessment, identifying the likely adverse impacts, incorporating the means of their prevention, and submitting the environmental impact study report accompanied by the necessary documents to the EPA or the relevant regional environmental agency.

- Ensure that an environmental impact assessment is conducted and an environmental impact study report is prepared by an expert who meets the requirements set forth by the directive issued by the EPA.

- Submit an environmental impact study report to the EPA or the relevant regional environmental agency for review.

\subsection{Uganda EIA Experience}

In Uganda, the responsibility to oversee, coordinate and supervise the operation of the EIA process is charged with the National Environmental Management Authority (NEMA). The basic EIA process in Uganda consists of three major stages: Screening, Environmental Impact Study, and Decision Making. The EIA itself is coordinated by NEMA, in conjunction the responsible Lead Agency (like a ministerial department under which the project falls) FAO, (1997).

The Screening stage has the objective of determining what level of EIA is required for a developmental project, whether a project has or does not have significant impacts. To be able to do this, a checklist is provided that categories which kind of EIA is required for the project. If the project is found to have significant impacts on the Environment, the Guideline 
recommends an EI Study to be carried out and an EI Statement be written for the project. Though before the study is done, Scoping procedure has to be carried out to identify the major Environmental Impacts to be studied. To carry out scoping the Guideline, leaves the responsibility to the discretion of the developer though monitors their operations, though a checklist is provided that can be used.

In carrying out the EI Study, the relevant data collected from Scoping is used, and the EIA team is supposed to go and collect data to address this data. The EIA team is expected to quantify the significant impacts and weigh them against a Threshold value to address the level of destruction of the impact. Though, no method is entailed in the Guideline to aid developers carry out this task.

After the EI Study, an EI Statement is written by the EIA team and submitted to NEMA for review, and the review is done in the next stage of the process. Under the Review Stage, the Environmental findings are reviewed in order to make a decision on Environmental Status of the project.

If the project is approved, developer is given a go-ahead notice in form of a "certificate of approval" and gives him the permission to go ahead and implement the project. During implementation stage,

\subsection{Kenya EIA Experience}

In Kenya, like Uganda the Environment matters are coordinated National Environmental Management Authority (NEMA). The EIA process in Kenya consists of four stages namely: Project Report, EIA study, Environmental Auditing, and Environmental Monitoring during the Project Report Stage, screening of the project is actually done, as done in Uganda. And if the project is found to have significant Environmental Impacts as shown the Project brief submitted to NEMA, an EI Study is recommended.

The EI study commends with the Scoping exercise, where the objective is to decide on focus the EIA team on what exactly what kind of work is required. This done by first identifying the major EIA concerns, briefing the EIA team on what kind of work is required, determine the assessment methods needed, and provide an opportunity for public involvement, and lastly establish the TOR's for the EI Study. With the TOR's the EI Study carried out.

During the Decision Making Stage, the NEMA reviews the Environmental findings, as well as the level of consultation of all stakeholders, then communicate the approval decision to the proponent, whether an approval or a disapproval of the project. Then the project can be implemented if approved.

In Kenya, its law for an Environmental Audit to be done on an ongoing project at least annually to establish the accuracy of the Environmental 
Prediction and mitigation. And an organ in NEMA is assigned this task to make sure that all on-going projects are audited.

\subsection{Rwanda EIA Experience}

The Government of Rwanda has just realized the significance of the Environment Impact Assessment, with the inception of the Rwanda Environmental Management Authority just in January 2004.

Though, EIA started to be practiced in 2002with no proper procedures. The EIA procedure involves five main stages: Screening, Scoping, and Preparation of the EIA report, EIA review and project appraisal, project Implementation.

In the Screening Stage, the aim is to decide the nature and extent of EIA to be carried out. This is done by determining the nature and magnitude of the proposed project potential environmental Impact, then categorize the project in either category A, B or C, depending on the level of EIA required for the project.

The Scoping Stage, is undertaken to identify the key Environmental Issues and thereafter determine develop the terms of reference for the EI study

In the Preparing of the EI Statement, a format is given of the information required to be included in the EI Statement.

In the Review Stage, the review the EI statement is done to find whether satisfactory information has been presented in the EI Statement for a decision to be made about the project. In the implementation stage, the project is implemented according to the conclusions derived from the EIA process. And the lead agency (the bank) supervises the implementation of the Environmental aspects of the project.

\subsection{Tanzania EIA Experience}

Tanzania adopted the first ever-comprehensive legal and institutional framework - that is, the Environmental Management Act Cap 191. This Act promotes Environmental Assessment, gives it the legal support and defines the institutional set up for the management of the environment. However, Tanzania still grapples with EIA ineffectiveness in guiding development decisions and environmental management arising from various projects. Numerous studies on the effectiveness of EIA have explored governance issues such as stakeholder participation, legislating EIA process, capacity building and institutional arrangement.

\section{COMPARISON WITH THE EU GUIDELINES}

In general, the EU guidelines also follow the same procedure but are more detailed for every stage. In every step, the EU guidelines give a step by 
step procedure of how the EIA process can be done for every stage in the EIA procedure. In addition, the EU guidelines go ahead to describe the tools or methods to be applied at every stage of the process, and what kind of information each tool can provide.

\section{COMPARISON WITH FAO GUIDELINES}

The procedure advocated for by FAO is almost the same as that of the NB countries, but the FAO guidelines include descriptively the two more steps of Environmental Monitoring and Audit (the NB countries' guidelines are silent about these guidelines).In addition, the FAO guidelines go ahead to describe the methods required to be applied at every stage of the EIA process, though not so much in detail like the EU guidelines.

\section{CONCLUSION AND RECOMMENDATIONS}

This paper has demonstrated the following weaknesses of international EIA guidelines:

- The guidelines leave a lot of discretion to the developer in carrying out an EIA except in the case of the US and WB guidelines.

- The level of public participation in the EIA process is not easy to measure, but public participation in the EIA process is required by all guidelines.

- Cost benefit analysis, risk assessment, and sensitivity analysis are not addressed by all guidelines.

- The EIA Guidelines of the NB countries do not adequately address the practical methods of assessing the impact at every stage of the EIA process and as such leave a lot of discretion to the developer.

- The Nile Basin EIA Country Guidelines need revision in order to upgrade current EIA practice in the Nile Basin.

- Cost Benefit analysis remains a vital component of environmental analysis

- In the NB countries, the EIA process is virtually the same, that is, consists of three major steps: Screening, Scoping, EI Study and EI Review. Though the following are the few weaknesses that need to be addressed in these guidelines,

- The guidelines leave a lot of discretion to the developer in carrying out an EIA.

- They all do not contain a description of the methods or tools to be applied when carrying out an EIA study at any stage of the process.

- The level of public participation in the EIA process is not easy to measure, many reports showed low levels of public participation in the EIA process. 
- On a positive side, many of the NB countries are still very young in this practice of EIA, and are showing tremendous improvement in its practice. With time, this process could be streamlined.

It is also concluding that there are Several key transboundary environmental issues have been identified in the Nile Basin:

(a) Exchange of information and knowledge sharing among and between key resource users, research institutions and other stakeholders throughout the Basin regarding best practices and lessons from experiences is very limited. Relatively few local stakeholders have access to adequate means of communications.

(b) Point and non-point source pollution can cross national boundaries and affect downstream riparian's. Soil erosion and non-point source pollution are serious problems in many areas in the Basin. Deforestation and soil erosion can lead to increased sedimentation and greater flood risks downstream, while sediments also accumulate in wetlands and reservoirs. Urbanization and industrialization often lead to greater pollution of the Nile River and its tributaries as pollution prevention and treatment measures generally do not keep pace with this development. Increased use and improper application of pesticides and fertilizers, especially in the large irrigation schemes in the northern reaches of the Basin, lead to increased runoff and pollution of drainage canals. All of these impacts have the potential to reach and harm downstream water users. Data and information related to the transboundary aspects of these issues are scarce and awareness of downstream impacts generally lacking. Only limited work has been done to identify environmental hot spots or to carry out systematic water quality monitoring at environmentally-sensitive sites of transboundary and regional significance. Moreover, there is insufficient understanding of the river basin dynamics to assess the downstream environmental impacts of future river system interventions or changes in watershed management regimes.

(c) Lack of capacity to perform adequate environmental impact assessments for planned investments and installations, although variable between the countries, is generally widespread throughout the Basin. This is either due to missing or outdated regulations or to insufficient enforcement of existing ones. While some countries have adopted environmental impact assessment guidelines relatively recently, the institutional capacity to enforce and monitor the process has been identified as generally poor. As a result, the capacity to assess the transboundary environmental impacts of planned basin-wide investment programs are currently insufficient to support a transition toward sustainable development.

(d) Water hyacinth and other invasive aquatic weeds have spread throughout many parts of the Nile Basin, impairing the functions of natural 
ecosystems, threatening fisheries and interfering with transportation. Programs are underway in the Basin to combat these invasive species and considerable progress has been made in the Lake Victoria region, largely supported by activities funded by the Lake Victoria Environmental Management Project.

(e) Water-dependent ecosystems throughout the Nile Basin contribute to the stability, resistance and resilience of both natural and human systems to stress and sudden changes. In particular, significant transboundary benefits derive from the Basin's wetlands. roles in maintaining water quality, trapping sediment, retaining nutrients, buffering floods, stabilizing micro-climates and providing storm protection. The ecological and economic role of wetlands in supporting sustainable development in the Basin is not well understood or widely appreciated.

(f) Key plant and animal species often have habitats in adjoining countries, requiring cross-border protected areas and other conservation measures for effective management. For example, the Nile is a principal flyway for birds migrating between central Africa and Mediterranean Europe, and Nile wetlands in a variety of countries provide indispensable habitats for these birds.

(g) Water-borne diseases such as malaria, diarrhea and bilharzia (schistosomiasis) are prevalent throughout the Basin and thus of major concern the Nile countries. Actions to curb these remain a priority in most of the Nile countries.

(h) Lack of awareness and understanding of the transboundary environmental consequences of the decisions being taken over land and water resource management in all of the riparian countries is a major barrier to strengthening environmental management.

(i) Environmental impacts of macro and sectoral policies on the Nile Basin’s land and water resources.

\section{The following recommendations are proposed;}

- Development of Unified EIA Guidelines for Nile Basin countries that address above mentioned weaknesses in the EIA process.

- Conduct refresher trainings for professionals in the Nile Basin countries

- Develop Data Bases for monitoring and evaluation of environment in the Nile Basin countries

- The use of scientific tools for impact quantification can be complicated, time consuming and very costly process, yet the development of empirical models can be a very useful tool during the screening and mitigation stages of EIA, however this tool need the following:

- Monitoring of river engineering structures in the Nile basin countries to collect a database of environmental correlations between 
parameters and impacts, between size and impact, between uses and impacts, and between local conditions and impacts.

- Collection of similar international experiences.

- Finally, from the analysis of different EIA guidelines for the NB countries and the International Organizations, the best EIA practice for the NB country projects is summarized as follows:

- Stage 1 - Develop a Project Proposal

- Stage 2 - Screening (leading to sectorial guidelines)

- Stage 3 - Scoping (under the sectoral guidelines of the project)

- Stage 4 - Prediction and Evaluation

- Stage 5 - Environmental Impact Review

- Stage 6 - Implementation

- Stage 7 - Environmental Monitoring

- Stage 8 - Environmental Audit

\section{References:}

Ahmed, M. I., and Abdella, L. D (2006). "Environmental Impact Assessment Legislation and Practice for the Environmental Management of Nile System with Special Reference to Sudan," Proceedings of the Nile Development Forum Conference. International Conference on "The Role of the River Nile in Poverty Reduction and Economic Development," UN-CEA Conference Hall.

Bryan Spooner, (1998), "Review of the quality of EIA guidelines, their use and circumnavigation" Environmental Planning Issues No. 19,

Canter, L.W. ,(1996), "Environmental Impact Assessment", McGraw-Hill Inc., Singapore.

Corbit R. A. ,(1990), Standard Handbook of Environmental Engineers, McGraw Hil.

Department of Environment Affairs (SA) (1992), “The Integrated Environmental Management Guidelines Series”.

Dougherty C., and Hall A. W (1995), "A Guide to the EIA of irrigation and drainage projects in developing countries", FAO.

European Commission, (1999), "Guidelines for the Assessment and Indirect and cumulative impact and interaction", EC,

,http://www.europa.eu.int/comm./environment.htm.

Emmanuel Olet [UNESCO-IHE],(2004), MSc. Thesis. 'Policy Management Support towards Preliminary Environmental Impact Assessment in the Nile basin'.

European Commission ,(1994), Environmental Impact Assessment Review Checklist. Directorate- General XI, ERM, R. Colley and K. Raymond (eds). FAO, (1995), “Environmental Impact Assessment of Irrigation and Drainage Projects”. 
FAO, (1997), Irrigation potential in Africa: A basin approach. Land and Water Bulletin No. 4.

FAO, (1997), Land and Water Development Division, ISBN 92-5-103966-6. http://www.fao.org.

Mason, S.A., (2003), From conflict to cooperation in the Nile basin. Thesis, Center for Security Studies, Swiss Federal Institute of Technology, Zurich, Switzerland., ISBN: 3-905641-95-X .

Mason, S.A., (2005), Are we scorpions? The role of upstream-downstream dialogue in fostering cooperation in the Nile Basin. Mountain Research and Development 25(2): 115-120.

NEMA, (1997), "Guidelines for Environmental Impact assessment in Uganda”.

International Association for Impact Assessment and the Institute of Environmental Assessment-UK( 1999).

Principles of Environmental Impact Assessment Best Practice", IAIA\P F\Principles, (January 1999).

World Bank (1999), "Environmental Department. Environmental Assessment Source Book" WB,1999. (Available on the internet: www.wb.org ).

World Bank,(1996), African Water Resources. Challenges and Opportunities for Sustainable Development.

World Bank,(1997), Water Pricing Experiences. Washington, DC: World Bank.

World Bank, (2000), African Development Indicators, Washington, DC: World Bank. 